\title{
The Effect of Safety Culture and Sense of Belonging on The Performance of Company Employees in Banten During the Covid-19
}

\author{
Santi Riana Dewi ${ }^{\mathbf{1}^{*}}$, Rt. Erlina Gentari ${ }^{2}$ \\ ${ }^{1,2}$ Fakultas Ekonomi dan Bisnis Universitas Serang Raya \\ Correspondent: santirianadewi@yahoo.co.id
}

$\begin{array}{ll}\text { Received } & \text { : June 12, } 2021 \\ \text { Accepted } & \text { : August 15,2021 } \\ \text { Published } & \text { : October 31, } 2021\end{array}$

Citation: Dewi, S.R., Gentari, R.E. (2021). The Effect of Safety Culture and Sense of Belonging on The Performance of Company Employees in Banten During the Covid-19. Ilomata International Journal of Management, 2(4), 242-253. https://doi.org/10.52728/ijim.v2i4.245

\begin{abstract}
During the COVID-19 pandemic, companies experienced changes in working hours and faced different work situations from before the pandemic. One of the most important things to face these challenges is how to maintain the performance of the company's employees so that they continue to give their best performance. This is due to health threats, changes in the work system, and changes in the environmental conditions faced. The novelty of the study when compared with previous studies is that there are differences in exogenous variables. The researcher analyzed the influence of the safety culture and sense of belonging variables on performance, which was processed using SMART PLS to determine the magnitude of the influence of each variable indicator. The research method used is a quantitative method with a survey approach. This study used a sample of 66 people who were obtained by random sampling technique, had a minimum of one year of work experience and were permanent employees of the company. Each variable will be tested for convergent validity, discriminant validity, reliability, $\mathrm{R} 2$, and significance. The results of the research based on the value of $\mathrm{R} 2$ show that the culture of safety and sense of belonging has an influence of $24.6 \%$ on performance. The safety culture indicators have a significant effect on performance with a $\mathrm{T}$ count $=4.655$, while the sense of belonging has a significant effect on performance with a $T$ count $=3.451$. Finally, it can be concluded from the results of research on employees of manufacturing companies in Merak Banten that both latent variables exogenous safety culture $\left(\mathrm{X}_{1}\right)$ and sense of belonging $\left(\mathrm{X}_{2}\right)$ with their indicators significantly affect performance $(\mathrm{Y})$. This means that by increasing the culture of safety and sense of belonging, it will be able to improve employee performance in the company.

Keywords: Performance, Safety Health, and Sense of Belonging.
\end{abstract}

This is an open access article under the CC-BY 4.0 license.

\section{INTRODUCTION}

This study was conducted with the aim of knowing how much influence the indicators of the safety culture and sense of belonging variables on employee performance in manufacturing companies in Banten. So that the research findings can be taken into consideration and company policy making as an effort to improve employee performance during the COVID-19 pandemic. 
The Effect of Safety Culture and Sense of Belonging on The Performance of Company Employees in Banten During the Covid-19 (Kristiana, Pramono, \& Brian, 2021).

As is well known during the pandemic, changes occurred in the work system, working hours, health threats, and internal and external working conditions of the company. The background of the research is the company's desire to be able to improve employee performance even though there are challenges during the pandemic (Byrnes et al., 2021). As it is known that the company's products are herbicides and fungicides, for the agricultural sector, these products will still be needed by the community even during the pandemic. Problem identification from the research still needs to be improved safety culture, sense of belonging, job satisfaction, and performance. The viability of a positive safety culture within the context of a diverse workforce, characterised by a reduced number of permanent employees, supplemented with more contingent and contract workers, is considered (Clarke, 2003).

In this study, it is limited to safety culture $\left(\mathrm{X}_{1}\right)$, sense of belonging $\left(\mathrm{X}_{2}\right)$ and performance $(\mathrm{Y})$. The formulation of the problem is whether there is an influence of safety culture on performance, whether there is an influence of sense of belonging on performance, and whether there is an influence of safety culture and sense of belonging simultaneously on performance. Furthermore, the method used is a quantitative method with a survey approach. The research hypothesis is as follows. $\mathrm{H}_{1}$ : There is a positive and significant influence of safety culture on performance; $\mathrm{H}_{2}$ : There is a positive and significant effect of sense of belonging on performance; $\mathrm{H}_{3}$ : There is a positive and significant influence of safety culture and sense of belonging on performance. Furthermore, the concept of the variable is explained as follows. Safety culture is a part of occupational safety and health that cannot be separated from the production process, both services and industry.

The development of development after Indonesia's independence led to the consequence of increasing the intensity of work which resulted in an increased risk of accidents in the work environment. Things that must be considered on safety culture are the management commitment, employee personnel attitude, coworkers safety support, workplace pressure, safety management system, violation behavior, personal safety motivation, and personnel error behavior. As for sense of belonging is an important aspect to study because of the impact interpersonal relationships have on an individual, and an individual's sense of belonging in an environment is dependent on the strength of relationships within that environment. In previous work-related studies on health care, sense of belonging was connected to work engagement, interaction, based on openness, mutual trust, respect, and appreciations. While performance is the success achieved by individuals in doing work, where the measure of success achieved can be equated with other individuals. achieved by the individual is based on the size applied and adapted to the type of work. Performance can be defined as the levels of needs of everyone, as a matter of the work given. There are two variables that determine a person's work performance, namely as follows: behavioral variables, including individual behavior and attitudes, work involvement, and work participation. Variable results that have been achieved for a performance, which includes four dimensions of performance consisting of: quality of output (quality of output), quantity of output (quantity of output), working time (time of output), cooperation with other co-workers (cooperation with other people's work). The four dimensions are interrelated with each other, for example, good cooperation between co-workers is directly affected by the quality and quantity of everyone's output (‥ Soegihartono, 2012).

The basic concept used in this study refers to previous studies related to the variables used, namely safety culture, sense of belonging and performance. The company's performance can be improved by identifying the factors that influence the performance improvement and analyzing 
how much influence these factors have on the company's performance, considering the culture of occupational safety and health (Ismail et al., 2021). Results can be obtained if the occupational safety and health culture in the company continues to be developed. Based on the model that shows the influence of occupational safety and health culture, work safety culture must start from top management on occupational safety issues, then the implementation of work safety plays an important role in improving the performance of company employees (Samaranayake et al., 2021). In accordance with the findings, the higher the occupational safety and health culture applied by top management, the higher the performance (Grinerud et al., 2021). So that conclusions can be drawn in accordance with research and literature which states that the implementation of occupational safety and health culture must start from top management (Christina et al., 2012).

Moreover, there is research consists of safety culture, safety climate and employee performance of PT Pelindo III. Based on the problem formulation, literature review, research results and discussion, it can be concluded that safety culture has a significant effect on the performance of employees of PT Pelindo III (Persero) East Java Province. The strong safety culture of PT Pelindo III (Persero) in East Java Province will have an impact on employee performance. The existence of this influence is due to the application of high work safety, employees will feel safe in carrying out their work considering that safety is an important thing in the work environment. Based on the condition of a strong safety culture at PT Pelindo III East Java Province, it can also direct employees to behave and act, because organizations that have a strong culture have values and codes of conduct for employees to perform. Furthermore, the safety climate has a significant effect on the performance of PT Pelindo III (Persero) employees in East Java Province. This shows that the safety climate can improve employee performance. This increase in employee performance is due to the attitude of the management of PT Pelindo III East Java Province towards employee safety and the availability of adequate safety equipment (Setiono, 2018).

In addition, safety (OHS) culture has a significant effect on employee job satisfaction, indicating that safety cultural values have a positive and significant effect on employee job satisfaction. The safety culture has a significant effect on employee job satisfaction, it can be accepted or proven true. Furthermore, safety culture has no significant effect on employee performance, indicating that safety cultural values have no significant effect on employee performance. Safety culture has a significant effect on employee performance which is rejected or not proven true. Furthermore, $\mathrm{K} 3$ culture has no significant effect on employee performance. This means that K3 cultural values have no significant effect on employee performance (Mulyono et al., 2013).

The other research states the following results. Most of the research respondents agree that safety (OHS) cultural factors, leadership, motivation are things that must be considered to increase employee job satisfaction. In relation to the performance of employees at the Oil and Gas company ' $\mathrm{X}$ ', the variables of leadership, motivation and job satisfaction of employees affect employee performance, this is different from safety culture which has no effect on employee performance. Others show that the influence of leadership, motivation and job satisfaction can be felt right away, so that the slightest changes that occur in these three variables will be felt immediately by employees, this is different from the influence of safety culture on employee performance, because the formation of an OHS culture is to be able to working safely alone will take a very long time and take a long process, so the willingness of employees to be able to work safely still needs leadership, systems, morale than employees who are friendly to employees to keep working safely (Marzuki et al., 2018).

Other findings show that running a company organization must have various resources, including capital and materials. In addition, the company also needs human resources, namely 
employees. Management of human resources must be done properly the effectiveness and efficiency of the organization can be increased. In general, the issue of occupational safety and health (K3) in Indonesia is still not given much attention. This is indicated by the high number of work accidents in Indonesia. This study aims to determine the effect of occupational safety and health on the performance of employees of PT Bimoli Bitung. Based on data analysis using multiple linear regression, it shows that the results of occupational safety and health have a significant effect on employee performance and have a positive relationship. Based on this, the company needs to pay attention to occupational safety and health in carrying out the company's operational activities, to improve the performance of the employees of the company Makadao et al., 2017).

Further research using SEM to explore the relationship between SCR (organizational consensus, safety commitment, and safety communication) and SPF (safety behavior, safety compliance, and safety participation), focusing on construction companies in Taiwan. Safety culture is found to have a certain predictive ability and effect on safety performance. It is observed that in Taiwan's construction industry SCR practices are most effectively established through ensuring worker commitment to safety. Effective safety communication channels should be established to allow workers to easily offer feedback on safety-related issues. Improvements to SPF allowed employees to better follow worksite SOP operations. Safety training and compliance practices are particularly important to ensure safety during potentially dangerous tasks, thus emphasizing the need for regular safety meetings and risk assessments. The results of this study also found that organizations with formal and permanently established SCR reduce the accident rate and enhance SPF. If SCR exists only at the construction site but not elsewhere in the organization, different standards between site managers may result in inconsistent practices and poor SPF. Recently, organizational focus on internal SCR has gradually increased, eclipsing SCT. Expert interviews conducted for this study also found that senior executives are concerned with the severity of accidents in Taiwan's construction industry, resulting from pressure to reduce costs and save time. Obviously, there is still considerable room for improvement. Although the conclusions drawn by this study can help enhance the comprehensiveness of safety management practices in the construction industry, it should be noted that SCR requires long-term development. Differences among various levels in terms of concepts, beliefs, or values will affect the effectiveness of SPF (Chen et al., 2018).

Overall, our results suggest an association between unit-level perceptions of safety culture and employee engagement over time in a large urban academic medical center. Future research is needed to understand temporal patterns and causal pathways more fully between engagement and the broader construct of patient safety culture; however, our results support conceptual arguments that patient safety and working environments that motivate and engage employees are meaningfully associated. Practically, these findings support the development of approaches to improving patient safety that pair human resource, development and leadership interventions with traditional safety and quality improvement approaches (Daugherty Biddison et al., 2016).

In addition, in the next case, it shows that employee, management, working environment, safety culture has positively influence OHS performance. The attributes of age, tribe, level of education, and gender contribute to the achievement of OHS performance in oil and gas industry. The Key Performance Indicators (KPI) found are PPE, fit for duty, human performance, communication, cooperation facilitation, hiring for safety training, safe task assignment, safety in design, housekeeping, OHS-industrial hygiene, environmental monitoring, gender, education level, age, and tribe. The findings suggest that the effect of management and working environment on OHS performance can be moderated by safety culture. While safety 
culture cannot moderate the relationship between employee and OHS performance. This can be evaluated for further research. Another moderator can be examined to obtain more information related to OHS performance as well as other independent variables and indicators considered. Research Implication The implications of this research are as follows: 1. Determining indicators of occupational health and safety; 2. Classifying indicators for input and output variables; 3. Calculating the value of significant relationships between variables using SPSS applications; 4. Creating target key performance indicators; 4. Searching the gap is found in the implementation of occupational health and safety rules; 5. Minimizing the gap for formulating improvements is conducted by making action items and achievement time targets called Specific, Measurable, Accountable, Relevant and Timeline (SMART) in order to reduce input and increase output as well. It also can be guided by OHSAS 18001 regarding occupational safety and health management (Sugiono et al., 2020).

Based on the results of previous studies, it can be concluded that safety culture which is part of occupational safety and health shows the results that safety culture has a positive influence on improving employee performance in various types of companies. There are several factors from the implementation of a safety culture to increase awareness of the importance of work safety to improve performance. As for this study, researchers conducted research on the influence of healthy culture on performance in manufacturing companies in Merak, Banten. During the pandemic, the company continued to produce products in the form of pesticides and plant protection products.

Furthermore, for the sense of belonging variable based on previous research, the following results were obtained. From the point of information economies and digital marketing examples and practice forms, although it is a relatively new medium, social media is rapidly developing. With this development, together with the personal usage areas (Eren \& Vardarlier, 2013), the corporate participation areas are expanding. As social media was a tool for Marketing and Communication it has started to be used in the fields of Human Resources and other bodies for different purposes.

By the principles of strategic management for businesses to achieve the objectives to perform the proper strategies and provide effective implementation of these strategies and in the same way must create an effective communication field. This communication to establish a business environment in the same way by building skills with internal clients and should feel the need to reach out to talents and keep them in the organization. In fact, the strategy established with stakeholders to achieve the most critical position in this network belongs to these talents. With this research, we have tried to see how personal use of the social media reflects in corporate use and with this to determine the social network use habits and their views on businesses/companies. The results that derived from the hypothesis evaluation, we could say that employees follow their organizations and their employers via social media and give importance to the messages that are shared by the employer through social media. Not only their give importance to the messages shared, but also the employer that is active on the social media has a parallel effect on the employee as his/her commitment is positively enhanced and the value put into the job done is increased likewise. When we look at the results of the hypothesis, Usage of social media in businesses have a direct effect on the sense of belonging $\left(\mathrm{H}_{1}\right.$, rejected) but we see a positive effect on the motivation of the employee $\left(\mathrm{H}_{2}\right.$, accepted). One of the effects we can see especially are acceptance of the increasing level of interaction between employees, but the varying number and dominance of factors involving sense of belonging to an organization through social media do not have a direct influence in the overall sense of belonging (Eren \& Vardarlier, 2013). 
Research carried out by different authors has attempted to highlight the link that could exist between the nature of leadership and the triggering of an intrapreneurial dynamic within companies. As we have reviewed, it has been possible to establish the relationship between transformational leadership and certain facets of intrapreneurship such as creativity or innovation. However, we note that there is a considerable lack in managerial literature, either in relation to the triggering factors or the outputs of the sense of belonging. This theoretical research is the first in this field, which highlights the role of the sense of belonging as a mediating variable conditioning the development of intrapreneurial capacities within companies. The proposed model will be the subject of an in-depth study and will soon be tested in the Moroccan professional environment (Slamti, 2020).

Furthermore, the findings indicate that questionnaires identified in this study to measure service quality, sense of belonging, and members participation exhibit acceptable psychometric properties in terms of both validity and reliability. There are three path relationships between variables tested in this study. Result has shown that service quality has influence significantly toward sense of belonging among co-operative's members. Sense of belonging, as well as service quality could be used as a predictor of members' participation among members to its cooperative. The greatest impact which founded in this study was the effect of service quality toward sense of belonging. All of results confirm the hypothesized relationship in the research model. Findings revealed that improved service quality will help in increasing sense of belonging and members' participation. These results confirmed the past research results. Out of the three paths relationship generated in this study, service quality was found to contribute maximum in influencing sense of belonging among member in state co-operative in Malang, East Java, Indonesia. Overall, these outcomes appear to be in line with the arguments that (i) service quality is importance of work in an enterprise such as co-operatives, and (ii) emotional attachment among co-operative members also important to generate more participation which could lead to greater profitability of co-operative enterprise. The results from this study were of particular interest given the absence to date of any empirical research linking service quality and members' participation in co-operative enterprise. Perhaps more open communication throughout co-operative enterprise to its members can facilitate further understanding of the influence of service quality on sense of belonging and members' participation. Hopefully this explanatory research effort will contribute to a better understanding of the nature of members' participation in co-operative enterprise. The recognition that the effects of service quality vary depending to its outcome is an important step in nurturing our understanding of service quality in co-operative. Even though the framework in this study has been validated in the context of Indonesia, especially in Malang, East Java, this study still has some limitations. First, the study was conducted only in general co-operatives in Malang, which this means that other cooperatives such as private co-operatives did not include as object in this study. The study did not include private co-operatives, and that is why to generalize it must be repeated in other and larger study samples. Future research also should employ alternative measures of sense of belonging and members' participation to identify greater external validity and consistency, because of an alternative measure could encompass a member's willingness to participate in cooperative enterprise (Hidayati, Hanif, et al., 2016).

Moreover, also found that good co-operative performance is not derived by members sense of belonging, but it generated by higher perceived service quality and members participation. But generally, results of this study provide strong support for the predictive power of perceived service quality on (1) attitudinal mechanism such as sense of belonging and members participation; and (2) organizational outcome such as performance. Our findings were consistent 
with the proposed research framework, which this was not surprising since the model was based on previous empirical findings and suggestions about developing integrated model in service quality - performance in context of co-operative enterprise. The importance of disciplined and consistent follow-through about co-operative practical knowledge is highlighted here. There is a need also to pay greater attention to this detail, particularly critical in the various enterprise. Service industries cannot recall their 'product'. Dissatisfied customers will simply go away. It is important for the management in co-operatives to understand the emotional attachment and participation among its members and giving support requirements for developing co-operative performance. To enhance the performance of co-operatives, there is a need to maintain members ${ }^{\text {ee }}$ attitudes. Thus, co-operative must have concern in establishing good service climate. In final model with reduced insignificant effect, we see that member participation have important role in mediate the effect of service quality and sense of belonging on co-operative performance. As a Co-operative Service Quality Co-operative Performance Co-operative Members Participation Members Sense of Belonging Co-operative Performance $\beta 3=0.270$ (Sign) part of attitudinal mechanism, sense of belonging founded have no important directly impact on cooperative performance. The result of structural equation model confirmed only one hypothesis are rejected. Findings of this study lead to some implications: First, members participation have important role in mediate the effect of service quality and sense of belonging on co-operative performance. Second, greater service quality perceived by members will increase sense of belonging, which this effect is the largest one. Overall, these outcomes appear to be in line with the arguments that (i) service quality is not only plays role as important antecedent of attitudinal or behavioral outcomes among co-operative members, but also for organizational performance outcome; and (ii) members participation is important factor in a social and economic enterprise such as co-operatives. Fine grained conceptual understanding of how this organizational dynamic in co-operative model is shaped in terms of members participation, thus contributing to a more comprehensive theoretical understanding of different organizational forms of cooperatives. A critical role for manager in co-operative enterprise to enhance the quality of service provided by every staff through formal and informal training and development. Feedback from members on their engagement contains element of quality. Refinement of the scale for measuring service quality in cooperative, proposed in this study, is certainly possible based on further trends in co-operative enterprise. In our view, this member participation deserves more attention in future research on co-operatives. Especially future empirical research is needed to both identify new pieces of theory, better define the connections between members participation and the other antecedents or outcomes, and to test emerging models (Hidayati, Pradesa, et al., 2016).

Further findings based on the results of other studies show the following conclusions. Based on the descriptive analysis on the sense of belonging variable, it shows that Bandung Techno Park employees already have a sense of belonging in the good category. It can be seen from the highest dimension in the sense of belonging is valued involvement. Meanwhile, based on descriptive analysis on employee engagement variables, it shows that the level of employee engagement in Bandung Techno Park is included in the good category, judging by the dimension of the highest employee engagement is "vigour". From the results of the T-test research conducted by researchers, the sense of belonging has a significant effect on employee engagement of Bandung Techno Park (Afryana, 2018). Based on the description of findings from previous research, it shows that sense of belonging can affect employee performance, job satisfaction, employee engagement, and organizational culture. The current researcher will analyze the effect of a sense of belonging on the performance of employees in a manufacturing 
company engaged in the production of pesticides and plant protection products in Merak, Banten.

\section{METHOD}

Research Locations and Research Subjects The research was conducted at a multinational manufacturing company in Merak Banten in 2020. The research subjects were safety culture, sense of belonging, and employee performance at PT NI. The research sample consisted of 66 company employees who had worked for at least one year and were permanent employees of the company. Collecting data in this study, the research instrument used was a questionnaire. Questionnaires that have been filled out by respondents are then processed using data processing programs, namely Excel and SMART PLS. The tests carried out include the significance test, reliability test, normality test, $\mathrm{T}$ test, and the coefficient of determination (R2) test. The indicators of healthy culture are management commitment, employee personnel attitude, coworkers' safety support, workplace pressure, safety management system, violation behavior, personal safety motivation, and personnel error behavior. Furthermore, indicators of a sense of belonging include a sense of pride, ability to work, obedience to rules, providing the best performance, and prioritizing the interests of the company.

Meanwhile, indicators of performance include productivity, responsibility, cooperation, work knowledge, and company interests. The research hypothesis consists of the first null hypothesis, namely that there is no influence of healthy culture on performance, and the second null hypothesis is that there is no effect of sense of belonging on performance. The first alternative hypothesis is that there is an influence of healthy culture on performance, while the second alternative hypothesis is that there is an influence of sense of belonging on performance. In this study, the structural equation model pays attention to the instrument items of each indicator of the variables and all sub-concept preparation items must meet the values of convergent validity, discriminant validity and good reliability values. Where a good validity value must be more than 0.5 , while a good reliability value must be more than 0.7 . If it is valid and reliable then further analysis can be done. The structural equation model used is the structural equation modeling equation (SEM).

\section{RESULTS AND DISCUSSION}

In the following, the results of the analysis of the influence of the safety culture and sense of belonging variables on employee performance are presented. First by designing the model, then evaluating the measurement model based on the results of the convergent validity test, discriminant validity test, and reliability test. Furthermore, the results of the evaluation of the structural model (Inner Model) based on the $\mathrm{R}^{2}$ test, and the significance test. This can be seen from the following figures and tables.

The design of the structural model can be seen from the figure below which shows that the exogenous latent variable of safety culture affects the endogenous latent variable of performance. And then the exogenous latent variable of sense of belonging affects the endogenous latent variable of performance. The following is a picture of the design of the research structural model. 


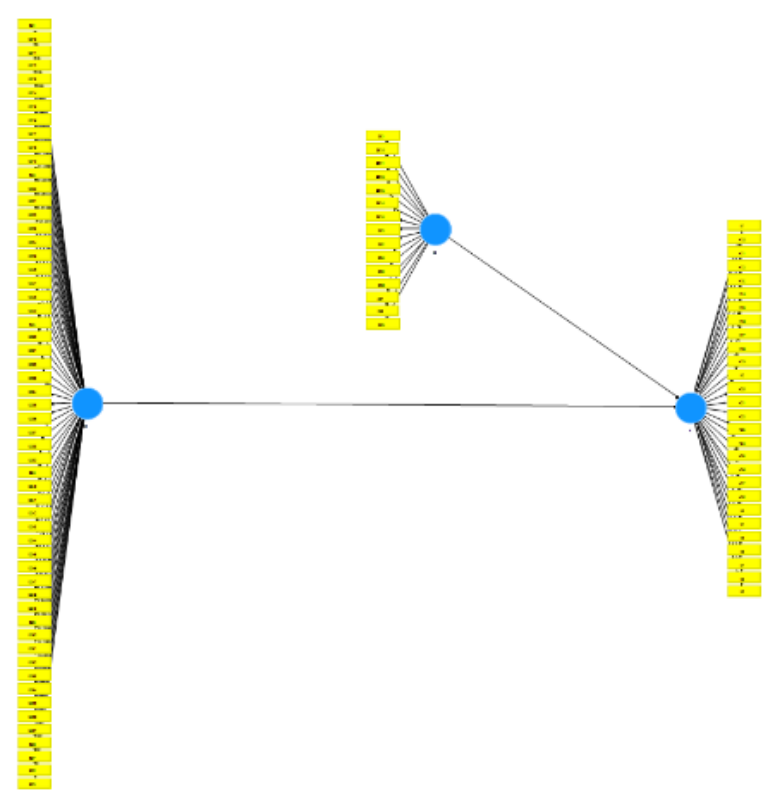

Figure 1. Research Model Design

Tabel 1. Output Result of Outer Loading

\begin{tabular}{|c|c|c|c|}
\hline & Safety Culture & Performance & Sense of Belonging \\
\hline BS42 & 0.802 & & \\
\hline BS48 & 0.771 & & \\
\hline BS9 & 0.860 & & \\
\hline K24 & & 0.808 & \\
\hline K25 & & 0.898 & \\
\hline SB10 & & & 0.767 \\
\hline SB12 & & & 0.748 \\
\hline SB14 & & & 0.746 \\
\hline SB7 & & & 0.723 \\
\hline SB8 & & & 0.729 \\
\hline
\end{tabular}

Table 1 shows the instrument items from the valid variables. In the Safety culture variable, there are three valid instruments, the Sense of belonging variable has five valid instruments, while from the Performance variable there are two instruments which are declared valid and can be analyzed further. Furthermore, the output loading factor modeling can be described as shown in the following figure.

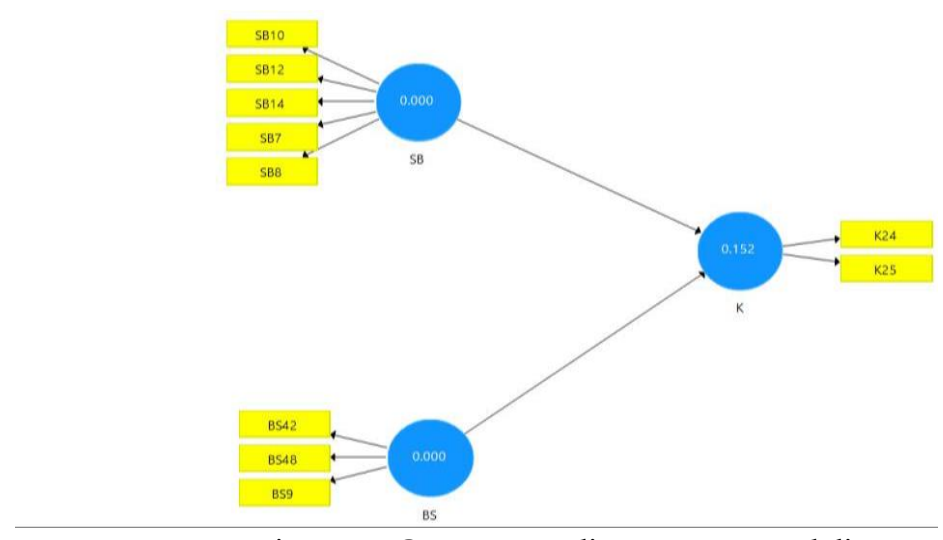

Figure 2. Output Loading Factor Modeling 
The Effect of Safety Culture and Sense of Belonging on The Performance of Company Employees in Banten

During the Covid-19

Dewi, \& Gentari

Table 2. Output of Cross Loading

\begin{tabular}{lccc}
\hline & Safety Culture & Performance & Sense of Belonging \\
\hline BS42 & 0.802 & -0.315 & -0.118 \\
\hline BS48 & 0.771 & -0.301 & -0.052 \\
\hline BS9 & 0.860 & -0.356 & 0.016 \\
\hline K24 & -0.277 & 0.808 & 0.241 \\
\hline K25 & -0.394 & 0.898 & 0.296 \\
\hline SB10 & 0.001 & 0.208 & 0.767 \\
\hline SB12 & -0.048 & 0.221 & 0.748 \\
\hline SB14 & -0.090 & 0.314 & 0.746 \\
\hline SB7 & 0.018 & 0.190 & 0.723 \\
\hline SB8 & -0.076 & 0.202 & 0.729 \\
\hline
\end{tabular}

Based on table 2, it can be shown that the data is valid because the interaction between the instrument concerned with the latent variable is greater than the interaction between the instrument and other variables.

Table 3. Results of Latent Variable Reliability Test

\begin{tabular}{lcccc}
\hline & $\begin{array}{l}\text { Cronbach's } \\
\text { Alpha }\end{array}$ & $\begin{array}{l}\text { Composite } \\
\text { Reliability }\end{array}$ & $\begin{array}{l}\text { Average } \\
\text { Variance } \\
\text { Extracted } \\
\text { (AVE) }\end{array}$ & Remarks \\
\hline Safety Culture & 0.741 & 0.853 & 0.659 & Reliable \\
\hline $\begin{array}{l}\text { Performance } \\
\text { Sense of }\end{array}$ & 0.637 & 0.844 & 0.730 & Reliable \\
Belonging & 0.801 & 0.860 & 0.552 & Reliable \\
\hline
\end{tabular}

Based on the value in table 3 shows the AVE value $>0.5$, the safety culture, sense of belonging and performance variables are declared reliable.

Table 4. Output Calculation of $\mathrm{R}^{2}$

Performance

$\begin{array}{cc}\text { R Square } & \text { R Square Adjusted } \\ 0.246 & 0.222\end{array}$

The value of R-squared (R2) is used to measure how much influence certain independent latent variables have on the dependent latent variable. So based on the table above, there is an $\mathrm{R}$ square value of $24.6 \%$, meaning that there is an influence of $24.6 \%$ between the safety culture and sense of belonging variables on performance.

Table 5. Calculation Results of Research Data Bootstrapping

\begin{tabular}{lccccc}
\hline & $\begin{array}{l}\text { Original } \\
\text { Sample (O) }\end{array}$ & $\begin{array}{l}\text { Sample Mean } \\
(\mathrm{M})\end{array}$ & $\begin{array}{l}\text { Standard } \\
\text { Deviation } \\
(\text { STDEV })\end{array}$ & $\begin{array}{l}\text { T Statistics } \\
(\mid \mathrm{O} / \text { STDEV } \mid)\end{array}$ & P Values \\
\hline $\begin{array}{l}\text { Safety culture } \rightarrow \\
\text { Performance }\end{array}$ & -0.383 & -0.388 & 0.082 & 4.655 & 0.000 \\
\hline $\begin{array}{l}\text { Sense of } \\
\text { belonging } \rightarrow\end{array}$ & 0.294 & 0.315 & 0.085 & 3.451 & 0.001 \\
\begin{tabular}{l} 
Performance \\
\hline
\end{tabular} & & & & & \\
\hline
\end{tabular}

It is known that the value of the T-table for the 95\% confidence level $(\alpha 5 \%)$ and the degrees of freedom $(\mathrm{df})=\mathrm{n}-2=66-2=64$ is 1.9977 . In testing the hypothesis, the influence of safety culture on performance is obtained, $\mathrm{T}$ count $=4.655>\mathrm{T}$ table $=1.9977$ the latent variable 
Safety culture and its indicators have a significant influence on the latent variable Performance. The original sample estimate value shows a positive value of -0.383 which indicates that the direction of the relationship between the Safety culture variable (X1) and the Performance variable $(\mathrm{Y})$ is negative. While testing the hypothesis of the effect of Sense of belonging on Performance, obtained $\mathrm{T}$ count $=3.451>\mathrm{T}$ table $=1.9977$ latent variable Sense of belonging and its indicators have a significant influence on latent variable Performance. While the original sample estimate value shows a positive value of 0.294 which indicates that the direction of the relationship between the Sense of belonging variable (X2) and the Performance variable (Y) is positive.

\section{CONCLUSION}

Based on the results obtained, it can be concluded that research on employees of manufacturing companies in Merak Banten shows the following results. The exogenous latent variable of Safety culture $\left(\mathrm{X}_{1}\right)$ has a significant effect on Performance, the latent variable of Sense of belonging $\left(\mathrm{X}_{2}\right)$ has a significant effect on Performance, and both the exogenous latent variable of Safety culture $\left(\mathrm{X}_{1}\right)$ and Sense of belonging $\left(\mathrm{X}_{2}\right)$ with their indicators influencing Performance $(\mathrm{Y})$ with its indicators significantly.

\section{REFERENCES}

Afryana, S. D. (2018). Pengaruh Employee Engagement terhadap Sense of Belonging (Studi di Bandung Techno Park). Jumal Indonesia Membangun, 17(2), 45-57. https://jurnal.inaba.ac.id/index.php/JIM/article/download/109/103/

Byrnes, K. P., Rhoades, D. L., Williams, M. J., Arnaud, A. U., \& Schneider, A. H. (2021). The effect of a safety crisis on safety culture and safety climate: The resilience of a flight training organization during COVID-19. Transport Policy. https://doi.org/10.1016/j.tranpol.2021.11.009

Chen, W. T., Wang, C. W., Lu, S. T., \& Pan, N.-H. (2018). The Impact of Safety Culture on Safety Performance: a Case Study of a Construction Company. International Journal of Organizational Innovation, 11(July), 301. https://www.researchgate.net/publication/326156228_THE_IMPACT_OF_SAFETY_C ULTURE_ON_SAFETY_PERFORMANCEA_CASE_STUDY_OF_TAIWAN'S_CONSTRUCTION_INDUSTRY

Christina, W. Y., Ludfi, D., \& Thoyib, A. (2012). Pengaruh Budaya Keselamatan Dan Kesehatan Kerja ( K3 ) Terhadap Kinerja Proyek Konstruksi. Jumal Rekayasa Sipil, 6(1), 83-95. https://rekayasasipil.ub.ac.id/index.php/rs/article/view/193

Daugherty Biddison, E. L., Paine, L., Murakami, P., Herzke, C., \& Weaver, S. J. (2016). Associations between safety culture and employee engagement over time: A retrospective analysis. BMJ Quality and Safety, 25(1), 31-37. https://doi.org/10.1136/bmjqs-2014-003910

Eren, E., \& Vardarlier, P. (2013). Social Media's Role in Developing an Employees Sense of Belonging in the Work Place as an HRM Strategy. Procedia - Social and Behavioral Sciences, 99, 852-860. https://doi.org/10.1016/j.sbspro.2013.10.557

Grinerud, K., Aarseth, W. K., \& Robertsen, R. (2021). Leadership strategies, management decisions and safety culture in road transport organizations. Research in Transportation Business \& Management, 100670. https://doi.org/10.1016/j.rtbm.2021.100670

Hidayati, N., Hanif, R., \& Pradesa, H. A. (2016). The Influence of Service Quality and Sense of Belonging 
toward Members , Participation in Co-operative Enterprise. 18(7), 56-65. https://doi.org/10.9790/487X-1807025665

Hidayati, N., Pradesa, H. A., Hanif, R., \& Sunaryo, H. (2016). Mediating Role of Members Participation and Sense of Belonging In The Effect of Service Quality on Co- operatives Performance Nur Hidayati Rifki Hanif Asia Malang Economy Science College Hadi Sunaryo. International Conference on Economics, Business and Social Sciences (ICEBUSS 2016), Icebuss.

https://www.academia.edu/30307639/Mediating_Role_of_Members_Participation_and_S ense_of_Belonging_In_The_Effect_of_Service_Quality_on_Co-_operatives_Performance

Ismail, S. N., Ramli, A., \& Aziz, H. A. (2021). Influencing factors on safety culture in mining industry: A systematic literature review approach. Resources Policy, 74, 102250. https://doi.org/10.1016/j.resourpol.2021.102250

Makadao, E., Kawet, L., Rondonuwu, C., Sam, U., \& Manado, R. (2017). Pengaruh Keselamatan Dan Kesehatan Kerja Terhadap Kinerja Karyawan Pt. Bimoli Bitung. Jurnal EMBA: Jurnal Riset Ekonomi, Manajemen, Bisnis Dan Akuntansi, 5(3), 4305-4312. https://doi.org/10.35794/emba.v5i3.18424

Marzuki, H., Sularso, R. A., \& Purbangkoro, M. (2018). Pengaruh Budaya Keselamatan Kerja, Kepimimpinan Dan Motivasi Terhadap Kepuasan Kerja Dan Kinerja Karyawan Pada Perusahaan Minyak Dan Gas Bumi "X" Di Propinsi Kalimantan Timur. Bisma, 12(1), 51. https://doi.org/10.19184/bisma.v12i1.7601

Mulyono, K., Program, M., Doktor, S., \& Ekonomi, I. (2013). Pengaruh Budaya K3 dan Gaya Kepemimpinan terhadap Kepuasan Kerja dan Kinerja Karyawan pada Divisi Operasi Tambang Di PT Newmont Nusa Tenggara. Jurnal Ilmu Ekonomi \& Manajemen, 9(1), 71-81. http://jurnal.untag-sby.ac.id/index.php/die/article/view/202/68

Samaranayake, A. I., Nishadya, S., \& Jayasundara, U. K. (2021). Analyzing Safety Culture in Sri Lankan Industrial Chemical Laboratories. Safety and Health at Work. https://doi.org/10.1016/j.shaw.2021.11.001

Setiono, B. A. (2018). Pengaruh Budaya K3 dan Iklim K3 Terhadap Kinerja Karyawan PT . Pelindo III ( Persero ) Provinsi Jawa Timur ( Effect of K3 Culture and K3 Climate on Employee Performance at PT . Pelindo III ( Persero ) East Java Province ) Benny Agus Setiono Jurusan Ketata. Jurnal Aplikasi Pelayaran Dan Kepelabuhanan, 9(1), 21-36. https://pdp-journal.hangtuah.ac.id/index.php/jurnal/article/download/39/32

Slamti, F. (2020). Linking Transformational Leadership, Sense of Belonging and Intrapreneurship. 51st International Scientific Conference on Economic and Social Development, March, 286. https://www.esdconference.com/upload/book_of_abstracts/Book_of_Abstracts_esdRabat2020_Online.pdf

Sugiono, N., Kusrini, E., Ali, J., \& Miranda, S. (2020). The Effect of Employee, Management, Working Environment, and Safety Culture on Occupational Health and Safety Performance: A Case Study in an Oil and Gas Company in Indonesia. The International Journal of Integrated Engineering, 12(7), 268-279. https://publisher.uthm.edu.my/ojs/index.php/ijie/article/view/3755 